\title{
Correlation of norms of federal and regional legislation as a condition for building an integrated system for regulating civil law relations (on the example of transport regulation)
}

\author{
Nina Semeryanova ${ }^{1}$, Anna Kopytova $^{2 *}$, Ludmila Dolnikova ${ }^{1}$ and Vladimir Morozkov ${ }^{1}$ \\ ${ }^{1}$ South Ural State University (National Research University), Nizhnevartovsk Branch, Mira str., 9, \\ 628600, Russia \\ ${ }^{2}$ Tyumen Industrial University, Volodarskogo str., 38, Tyumen, 625000, Russia
}

\begin{abstract}
The urgency of the problem under investigation is caused by the contradictions between regional and federal legislation in the regulation of civil relations, which hamper the optimization and achievement of the balance of the Russian legislative framework. Such contradictions are most clearly seen in the field of transport law. The purpose of the article is to update the problematic issues of the correlation between the norms of regional and federal legislation, the issues of delimitation of private and public regulation. The leading approach to the study of this problem is dialectics, analysis, synthesis, deduction, formal-legal method. The analysis can help to understand the formative elements of law governing the legal field of private and public regulation, the adoption of regional instruments that contribute to the full and comprehensive regulation of civil relations, including the field of transport commitments.
\end{abstract}

\section{Introduction}

The effectiveness of the functioning of the state economy is determined by ensuring the sustainable development of its regions. Regions are characterized by the size of territories, administrative-territorial division, the distribution of human resources, natural resources, climatic, cultural features, the level of socio-economic development, existing regional problems, etc. [1-4] The sustainable development of the territory depends on the balance of interests of the systems (political, social, economic and environmental) both between the countries of the world and the regions of any state. In regions of the Russian Federation, the sustainability of territories is largely determined by a scientifically based state policy aimed at improving the quality of life of the population. [5-8] Achieving the harmonization of the needs of society and the interests of an individual is carried out by legal regulation, including regional legal regulation.

\footnotetext{
* Corresponding author: a.copytowa@yandex.ru
} 
Legislation as a whole is a complex, diversified formation, where there are many differences, disagreements, inconsistencies, competing and conflicting norms and institutions. These shortcomings violate the internal consistency in the system of legislation, lead to a decrease in its effectiveness, impede the implementation of the objectives of legislative regulation, reduce its effectiveness. [1]

The current state of civil legislation can be characterized as dynamically developing. The reform of civil legislation under way has affected most of the provisions of the Civil Code of the Russian Federation [5], in particular, provisions on civil rights objects, legal entities, rights to the results of intellectual activity and means of individualization, obligations, etc. The modernization concept is also aimed at reforming property law. Bringing the norms of legislation in line with modern civil circulation is expressed in a change in its internal content, as well as in the formation of new institutions. Such a tendency echoes on the legislation of the subjects of the Russian Federation, which, in turn, leads to quite complex processes in the enforcement of law.

\section{Methods}

The theoretical basis of the study includes the norms of domestic legislation in the field of civil law regulation, as well as the position of scientists on the problem aspects of regulation of relations by the norms of public and private branches of law (A.Akharkhin, S. Artemova, N. Kremlev and others). The following scientific methods were used in the work: dialectics, analysis, synthesis, deduction, formal-legal method, comparative legal method.

The comparative legal method made it possible to correlate federal legislation with the developing legislation of the subjects of the Russian Federation in the sphere of civil law regulation, identify inconsistencies, and analyze shortcomings in regional legislation. The results of the research can contribute to more effective regulation and enforcement of existing norms in the field of civil law in the regions. The dialectical method allowed to thoroughly investigate the nature of such contradictions; analysis, synthesis, deduction allowed to analyze disputable issues in doctrine and practice, such as cross-sectoral contradictions in the regulation of the same legal relations, for example in the field of land and civil law, medical law, etc.

\section{Results}

1. Civil legislation does not apply to the subject of joint jurisdiction of the Russian Federation and the constituent entities of the Russian Federation (clause "o" Article 71 of the Constitution of the RF [7]). At the same time, the Constitution of the Russian Federation does not exclude the normative activities of subjects of the Russian Federation in the field of civil legislation in the subjects of joint of the Russian Federation and its subjects. Issues of joint jurisdiction are fixed in Art. 72 of the Constitution of the RF.

However, despite the fact that laws and other legal acts of the subjects of the Russian Federation should not contradict federal laws governing civil legal relations, it happens that acts of lawmaking of the subjects of the Russian Federation violate this legislative requirement. Most often, this happens when an attempt is made to broaden the interpretation of certain regulatory issues, which are based, first of all, on the regional individuality of the subject, its identity and the specifics of development. The very tendency towards resolving many specific issues in the region can be recognized as positive and justified, since regional legislation should not copy the federal one, issues of regional 
competence (not related to the sphere of federal jurisdiction and to the sphere of joint jurisdiction) should be regulated by regions independently.

As it is rightly pointed out by A.V. Azarkhin, some regional acts not only specify the provisions of the federal legislation, but also develop it with reference to a specific subject of the Russian Federation, supplemented by new norms. And here, it is necessary to control that the regional act does not contrast with the federal legislation, but, on the contrary, elaborate and develop it without entering into contradictions with it [2].

Of course, the freedom of the regions should not lead to contradictions with civil law and violate the norms of the Constitution of the Russian Federation, which directly establishes the priority of the federal law (Article 76 of the Constitution of the Russian Federation). However, this problem still remains relevant.

So, for example, in the resolution of the Federal Arbitration Court of the Volga-Vyatka okrug of July 2, 2013, in case No. A28-10757 / 2012, issues of the correlation of the laws of the subjects of the Russian Federation on public-private partnerships and public procurement legislation were considered [13]. In particular, the Department of Road Economy and Transport of the Kirov region has developed the documentation for determining the private partner by concluding and executing the agreement on publicprivate partnership and held a tender to determine the private partner for road works on the public roads of the Kirov region of regional or intermunicipal significance and artificial structures on them with use on terms of risk sharing, competence and responsibility, by concluding and applying An agreement on public-private partnerships.

When considering the case, in the opinion of the Department, the courts did not take into account Federal Law No. 184-FZ of 06.10.1999 "On general principles for the organization of legislative (representative) and executive bodies of state power of the subjects of the Russian Federation" [18] and the Kirov Region Law of 04.06. 2010 N 529$\mathrm{ZO}$ "On the participation of the Kirov region in the projects of public-private partnership", in this connection, the findings of the courts do not correspond to the case materials.

In the opinion of the Supreme Court of the Russian Federation, the placement of orders for the supply of goods, the performance of work, or the provision of services for state or municipal needs shall be made in accordance with the legislation of the Russian Federation on the placement of orders for state and municipal needs (Article 72 of the RF Budget Code) [4], in the manner provided for Art. 10 and 55 by Law No. 94-FZ, through the holding of an auction (now expired in connection with the adoption of Federal Law No. 44FZ of 05.04.2013 (edition of July 29, 2017) "On the contract system in the procurement of goods, works, services to ensure state and municipal needs "[19]). According to paragraph 2 of Part 1 of Art. 15 of the Law No. 135-FZ "On Protection of Competition" [20], federal executive bodies, state authorities of the subjects of the Russian Federation, local selfgovernment bodies and other persons performing the functions of these bodies are prohibited from accepting acts and / or carrying out actions (inaction), which lead or can lead to the prevention, restriction, elimination of competition, except for the cases of adoption of acts and (or) the implementation of such actions (omissions) provided for by federal laws. In particular, it is prohibited to unreasonably interfere with the activities of economic entities, including by establishing requirements for goods or economic entities not provided for by the legislation of the Russian Federation. The prohibition established by this rule extends primarily to the acts and actions of public authorities in the field of public legal relations in order to prevent their negative interference in the competitive environment by using administrative tools.

Thus, it is a question of inadmissibility of establishment by the law of the subject of the Russian Federation of agreements on the subject similar with a subject of the contract on purchase for the state and municipal needs. Such actions lead to the risk of recognition of such agreements as invalid. Also, it should be noted that the acts of the subjects of the 
Russian Federation can not oblige business entities to enter into transactions, since this is the exclusive competence of the Russian Federation in the sphere of civil regulation.

2. As another example, the definition of the Supreme Court of the Russian Federation of 28.10.2015 No. 65-APG15-5 "On leaving unchanged the decision of the court of the Jewish Autonomous Region of 21.07.2015" [11], which was partially satisfied with the declaration on the recognition of inactive individual the provisions of the Law of the Jewish Autonomous Region on 18.07.2012 № 122-OZ "On particular issues of protecting the health of citizens in the territory of the Jewish region", not to include in the law provisions on a group of people entitled to preferential provision of medicines and (or) (paramedics) for out-patient treatment of pensioners who receive old-age, disability or survivors' pension in minimum amounts, which contradict federal legislation and reduce the level of guarantees in the field of health protection for Russian citizens residing in the territory of the Jewish Autonomous Region.

In this case, we are talking about a regional law that did not name the group of people eligible for benefits, in accordance with the List of Outpatient Treatment Groups, approved by the Government of the Russian Federation from 30.07.1994 No. 890 "On State Support for the Development of the Medical Industry and Improving the Security population and institutions of public health with medicinal products and medical devices "[14]. Thus, the preferential category of citizens of the region remained without state social support. Such an intrusion of regional bodies in the competence of government bodies of the Russian Federation leads to the fact that at the level of regional legislation there is a discreteness of legal regulation. In addition, it should be noted that state guarantees are the sphere in which private and public regulation is most often confused.

3. In this connection, it is appropriate to refer to the practice of the Supreme Court of the Russian Federation, where the controversial regulation is defined as the sphere of state regulation, and the regional executive authorities of the subjects of the Russian Federation are entitled to introduce state regulation of tariffs and allowances, which can not be considered as contradicting civil legislation.

In the first case, citizen appealed to the Supreme Court of the Russian Federation with a request to recognize as inoperative clause 112 of the Rules for connecting (technological connection) capital construction facilities to gas distribution networks, in part prohibiting the applicant from taking measures to connect the capital construction object to the gas distribution network (except for activities related to the expansion of the throughput the capacity of the existing gas distribution network) outside the applicant's land plot, as well as the registration of the capital constructions built outside its area by the applicant, where the maximum hourly flow of gas in gas-powered equipment is less than 500 cubic meters, and the design working pressure in the attached pipeline is $0.6 \mathrm{M} 3 \mathrm{pa}$ or less. The applicant disputes the provisions of the normative legal act as contradicting paragraphs 1 and 2 of Art. 129, 218, 421, 703 of the Civil Code of the Russian Federation and violating the rights and freedoms of citizens, guaranteed by the Constitution of the Russian Federation [15].

According to the court, the arguments of the applicant about the contradiction of the contested provisions of the normative legal act to the articles of the Civil Code of the Russian Federation are untenable, since they do not establish any restrictions on the ability to repay civil rights objects, the grounds for acquiring the property right and the prohibition on performance of work under the contract. Connection to gas distribution networks outside the boundaries of the land plot belongs to the sphere of state regulation and is implemented in accordance with the fixed and standardized tariff rates for connection established by the regional executive authorities, except for setting connection rates for individual projects (Paragraph 112 of the Rules) has a contractual value. Implementing its powers in the field of gas supply, the Government of the Russian Federation in paragraph 112 of the Rules provided for the possibility of adjusting the amount of payment for technological 
connection when it is determined by an individual facility, which can not be regarded as a contradiction to civil legislation.

In the second case, the Appeals Board of the Supreme Court of the Russian Federation considered the case on the recognition of a partially inoperative para. 7 List of services of transport, supply and marketing and trade organizations for which the executive authorities of the subjects of the Russian Federation are given the right to introduce state regulation of tariffs and allowances, Decree of the Government of the Russian Federation of March 7, 1995 No. 239 [3], in particular, on transport services for the carriage of goods, passengers and luggage by sea, river and air transport in the Far North and equivalent areas. The applicant refers to the contradiction of the provisions of the normative legal act of clause 1 and 2, art. 790 Civil Code, art. 6 of the Code of Inland Water Transport of the Russian Federation [9], paragraph 1 of the Decree of the President of the Russian Federation of February 28, 1995 No. 221 "On measures to streamline the state regulation of prices (tariffs)" [17], and believes that they are published with excess authority, granted to the Government of the Russian Federation, violate the rights of OJSC "Lena United River Shipping Company" for the free exercise of business activities. FKZ of 17.12.1997 No. 2FKZ "On the Government of the Russian Federation" [21] refers to the development and implementation of measures to conduct a unified price policy to the powers of the highest executive body of state power in the RF in the sphere of budgetary, financial, credit and monetary policy. Consequently, established by the paragraph 7 of the List, right of the executive authorities of the constituent entities of the Russian Federation to introduce state regulation of tariffs and surcharges for transport services for the carriage of goods, passengers and luggage by sea, river and air transport in the Far North and equivalent areas corresponds to the current legislation of the Russian Federation.

4. Another case is noteworthy, because it demonstrates the delineation of the spheres of regulation not only of civil and land law, but also of the sphere of federal and regional legislation, insofar as it gives powers to the subjects of the Russian Federation to implement state regulation on issues of joint jurisdiction with the Russian Federation.

The decision of the Supreme Court of the Russian Federation of February 20, 2013 No. 78APG13-1 on the case of invalidating the Resolution of the Government of St. Petersburg of 10.04.2007 № 378 "On the procedure for interaction of the executive bodies of state power in St. Petersburg with the seizure of land for state needs of Saint- Petersburg "[12], the applicant considers that the contested normative legal act is inconsistent with the requirements of Art. 9, 49, 55 of the Land Code of the Russian Federation [6] and art. 3, 279 of the Civil Code of the Russian Federation, which violates his rights and freedoms. Denying the applicant the satisfaction of the claims, the court proceeds from the fact that the challenged decree of the Government of St. Petersburg does not determine the procedure for seizing land plots for state needs and is an act that ensures the implementation of the authority for the seizure of land granted to the subject of the Russian Federation. The definition of the procedure for preparation and adoption of decisions on the seizure of land for state needs is attributed to the area of the federal land legislation by the Civil Code of the Russian Federation. The Land Code of the Russian Federation, which is an act not only equal in the legal force of the Civil Code of the Russian Federation, but also an act that is later and special, regulating disputable relations, refers to the powers of the Russian Federation only to determine the procedure for the seizure of land plots, including redemption, for state and municipal needs.

In the Russian Federation in the period of 2013-2018 there has already been a positive dynamics of judicial practice on contentious regulation [16]. The qualitative acts of the constituent entities of the Russian Federation do not contradict federal legislation, but they implement the state policy in the sphere of regulation, both private and public interests. 


\section{Discussion}

Effective regulation of civil legal relations, correlation with the norms of intersecting branches of law in modern legislation is a necessary condition for a stable civil and legal turnover. The conclusions reached in the work can contribute to the further improvement of civil legislation; improve the effectiveness of the implementation of the rights of subjects of civil legal relations. The results of the work can be used as a basis for further research in the field of regional legislation on the establishment of regulations not using civil law regulation, but using other branches of law - administrative, land, environmental, etc., in particular, consideration of the problems of the adoption of regional acts committing to enter into transactions subjects of entrepreneurship, thereby violating the rules of private law regulation.

\section{Conclusion}

Thus, the problem of improving regional legislation is currently very relevant. Conflicts of rules of law cause legal contradictions, thereby violating the process of implementing the norms of law and their application. Therefore, balanced legal acts eliminate legal contradictions, which is an important aspect of civilized regulation of public relations.

\section{Acknowledgments}

The work was supported by Act 211 of Government of the Russian Federation, contract No 02 . A03. 21. 0011 .

\section{References}

1. S.Yu. Artemova, Forum. Series: Humanities and Economics, (5), 154-159 (2015)

2. Russian Federation Government Resolution No. 239 of March 7, 1995

3. A.V. Azarhin, Questions of Russian and International Law, 7, 12-22 (2016)

4. N. Zotkina, M. Gusarova, A. Kopytova, Advances in Intelligent Systems and Computing 692, 1204-1213 (2018) DOI: 10.1007/978-3-319-70987-1_129

5. A. Kopytova, Procedia Engineering 165, 1132 (2016) DOI: 10.1016/j.proeng.2016.11.830

6. The appellate ruling of the Supreme Court of the Russian Federation of 17.03.2015 No. APL15-69 of December 18, 2014 No. AKPI14-1241

7. Budget Code of the Russian Federation No. 145-FZ of July 31, 1998 (as amended on September 30, 2017)

8. The Civil Code of the Russian Federation (Part One) of November 30, 1994 No. 51 FZ (as amended on July 29, 2017) (as amended and supplemented, effective from 06.08.2017)

9. The Land Code of the Russian Federation No. 136-FZ of October 25, 2001 (as amended on July 29, 2017) (as amended and supplemented, entered into force on August 11, 2017)

10. The Civil Code of the Russian Federation (part one) of November 30, 1994 No. 51-FZ (as amended on July 29, 2017) (with amendments and additions, effective from 06/08/2017) 
11. The Land Code of the Russian Federation of October 25, 2001 No. 136-FZ (as amended on July 29, 2017) (with amendments and additions, entered into force on August 11, 2017)

12. A. Kopytova, MATEC Web of Conferences, 106, 08056 (2017) DOI: $10.1051 /$ matecconf/201710608056

13. Decision of the Supreme Court of the Russian Federation of 10.11.2014 No. AKPI141095 Decree of the Government of the Russian Federation of December 30, 2013 No. 1314

14. N. Zotkina, A. Kopytova, M. Zenkina, O. Zhigunova, MATEC Web of Conferences, 106, 08058 (2017) DOI: 10.1051/matecconf/201710608058

15. Fedorov, M., Matys, E., Kopytova, A. E3S Web of Conferences, 33, 03054 (2018) DOI: $10.1051 / \mathrm{e} 3$ sconf $/ 20183303054$

16. Decree of the President of the Russian Federation No. 221 of February 28, 1995 (as amended on April 30, 2016)

17. Russian Federal Law No. 44-FZ of 05.04.2013 (edition of July 29, 2017)

18. N. Zotkina, S. Bardasov, M. Gusarova, A. Kopytova, MATEC Web of Conferences, 106, 08050 (2017) DOI: 10.1051/matecconf/201710608050

19. K. Pykhtin, T. Simankina, V. Sharmanov, A. Kopytova, IOP Conference Series: Earth and Environmental Science, 90 (1), 012065 (2017) DOI: 10.1088/1755$1315 / 90 / 1 / 012065$

20. V. Lezier, M. Gusarova, A. Kopytova, IOP Conference Series: Earth and Environmental Science, 90 (1), 012034 (2017) DOI: 10.1088/1755-1315/90/1/012034

21. A. Minnullina, R. Abdrazakov, Advances in Intelligent Systems and Computing 692, 1224-1233 (2018) DOI: 10.1007/978-3-319-70987-1_131 